\section{Human immunodeficiency virus: an unacceptable term}

SIR-In the 1 May issue of Nature and 9 May issue of Science, the International Committee on the Taxonomy of Viruses recommended that the LAV/HTLV-3 (AIDS) virus be renamed human immunodeficiency virus (HIV). Although two of the members refused to sign the recommendation, the term HIV has been increasingly used - not only in the scientific literature but also in the media. I would urge that this practice be discontinued and that a new name be selected quickly because an important argument against the term HIV has been neglected.

The views of the small group of patients suffering from the various genetically or constitutionally determined immunodeficiency syndromes, (such as Bruton's type or common variable immunodeficiency) had apparently not been obtained. These patients are doing their best to cope with a disease that has nothing to do with sexual transmission or the other circumstances which are involved in virus contraction in many cases of AIDS. For many patients with an immunodeficiency that is unrelated to AIDS, the massive public discussion about AIDS has come as an extra personal difficulty. Not everybody with whom they are in contact will distinguish between genetically determined and virus-induced disease and the term HIV will add an unnecessary burden to their lives. It is the responsibility of the medical professions to avoid this problem.

Per Brandtzaeg Laboratory for Immunohistochemistry and Immunopathology, Rikshospitalet, 0027 Oslo 1, Norway

\section{Screwworm eradication is what it seems}

SIR-Under the heading 'Screwworm eradication, a grand delusion' Readshaw' appears to belittle the effects of the campaign to eradicate the screwworm fly (Cochliomyia hominovorax) from the southern United States and Mexico. He claims that most, if not all, of the changes in screwworm incidence in Texas can be explained on a model in which the number of cases in a season depends on the number of cases in the previous season and on the state-wide average temperature for the season.

A more detailed look at this hypothesis using the climatological divisions of Texas and the recorded screwworm incidence for each of the four seasons 1962-83 shows that most of the supposed explanatory power of this model is merely the result of the autocorrelation of the numbers of screwworms in one season and the next; temperature and rainfall only contribute a

\begin{tabular}{|c|c|c|c|c|c|}
\hline \multirow[b]{2}{*}{ Division } & \multirow[b]{2}{*}{ Season } & \multirow{2}{*}{$\begin{array}{l}\text { Past } \\
\text { cases } \\
\left(r^{2}\right)^{*}\end{array}$} & \multirow{2}{*}{$\begin{array}{c}\text { Full } \\
\text { regression } \\
\left(r^{2}\right)^{*}\end{array}$} & \multicolumn{2}{|c|}{ Probability $^{\dagger}$} \\
\hline & & & & Temp. & Rain \\
\hline Valley & $\begin{array}{l}\text { Winter } \\
\text { Spring } \\
\text { Summer } \\
\text { Autumn }\end{array}$ & $\begin{array}{l}0.42 \\
0.67 \\
0.77 \\
0.79\end{array}$ & $\begin{array}{l}0.39 \\
0.63 \\
0.94 \\
0.80\end{array}$ & $\begin{array}{l}0.39 \\
0.85 \\
0.04 \\
0.10\end{array}$ & $\begin{array}{l}0.76 \\
0.79 \\
0.30 \\
0.21\end{array}$ \\
\hline Southern & $\begin{array}{l}\text { Winter } \\
\text { Spring } \\
\text { Summer } \\
\text { Autumn }\end{array}$ & $\begin{array}{l}0.47 \\
0.77 \\
0.83 \\
0.86\end{array}$ & $\begin{array}{l}0.52 \\
0.75 \\
0.88 \\
0.87\end{array}$ & $\begin{array}{l}0.10 \\
0.84 \\
0.03 \\
0.93\end{array}$ & $\begin{array}{l}0.98 \\
0.83 \\
0.99 \\
0.11\end{array}$ \\
\hline South-central & $\begin{array}{l}\text { Winter } \\
\text { Spring } \\
\text { Summer } \\
\text { Autumn }\end{array}$ & $\begin{array}{l}0.32 \\
0.60 \\
0.86 \\
0.84\end{array}$ & $\begin{array}{l}0.51 \\
0.71 \\
0.88 \\
0.83\end{array}$ & $\begin{array}{l}0.06 \\
0.22 \\
0.22 \\
0.31\end{array}$ & $\begin{array}{l}0.58 \\
0.01 \\
0.69 \\
0.97\end{array}$ \\
\hline East & $\begin{array}{l}\text { Winter } \\
\text { Spring } \\
\text { Summer } \\
\text { Autumn }\end{array}$ & $\begin{array}{c}0 \\
0.88 \\
0.91\end{array}$ & $\begin{array}{cc}0 \\
0.88 \\
0.93\end{array}$ & $\begin{array}{l}- \\
0.82 \\
0.84 \\
0.03\end{array}$ & $\begin{array}{c}- \\
0.99 \\
0.24 \\
0.06\end{array}$ \\
\hline Edwards plateau & $\begin{array}{l}\text { Winter } \\
\text { Spring } \\
\text { Summer } \\
\text { Autumn }\end{array}$ & $\begin{array}{l}0.27 \\
0.47 \\
0.77 \\
0.88\end{array}$ & $\begin{array}{l}0.38 \\
0.41 \\
0.84 \\
0.87\end{array}$ & $\begin{array}{l}0.90 \\
0.93 \\
0.02 \\
0.81\end{array}$ & $\begin{array}{l}0.09 \\
0.97 \\
0.98 \\
0.53\end{array}$ \\
\hline Trans Pecos & $\begin{array}{l}\text { Winter } \\
\text { Spring } \\
\text { Summer } \\
\text { Autumn }\end{array}$ & $\begin{array}{c}0 \\
0.18 \\
0.84 \\
0.83\end{array}$ & $\begin{array}{c}0 \\
0.21 \\
0.94 \\
0.82\end{array}$ & $\begin{array}{l}0.2 \\
0.28 \\
<0.01 \\
0.39\end{array}$ & $\begin{array}{l}0.76 \\
0.14 \\
0.46 \\
0.38\end{array}$ \\
\hline Low plains & $\begin{array}{l}\text { Winter } \\
\text { Spring } \\
\text { Summer } \\
\text { Autumn }\end{array}$ & $\begin{array}{c}0 \\
0 \\
0.81 \\
0.79\end{array}$ & $\begin{array}{c}0 \\
0 \\
0.87 \\
0.77\end{array}$ & $\begin{array}{c}0.19 \\
0.11 \\
<0.01 \\
0.38\end{array}$ & $\begin{array}{l}0.94 \\
0.90 \\
0.57 \\
0.86\end{array}$ \\
\hline
\end{tabular}

* Coefficients of determination adjusted for the degrees of freedom.

$\dagger$ Testing the null hypothesis that temperature or rainfall regression coefficients are zero.

Table 2 Mean winter and summer temperatures and total reported screwworm cases by Texas climatological division, 1962-83

\begin{tabular}{|c|c|c|c|c|}
\hline \multirow[b]{2}{*}{ Region } & \multicolumn{2}{|c|}{ Winter* } & \multicolumn{2}{|l|}{ Summer $^{\dagger}$} \\
\hline & $\begin{array}{c}\text { Temperature } \\
\left({ }^{\circ} \mathrm{F}\right)\end{array}$ & Cases & $\begin{array}{c}\text { Temperature } \\
\left({ }^{\circ} \mathrm{F}\right)\end{array}$ & Cases \\
\hline Low Plains & 43.2 & 2 & 81.4 & 4,020 \\
\hline Trans Pecos & 46.8 & 11 & 80.1 & 9,270 \\
\hline East Texas & 47.6 & 0 & 80.9 & 2,868 \\
\hline Edwards Plateau & 47.8 & 137 & 81.3 & 22,951 \\
\hline South Central & 53.4 & 103 & 82.9 & 17,263 \\
\hline Southern & 55.5 & 830 & 84.6 & 19,265 \\
\hline Lower Valley & 59.7 & 194 & 83.9 & 3,340 \\
\hline Totals & & 1,277 & & 78,977 \\
\hline Means & 50.57 & & 82.16 & \\
\hline Standard deviation & 5.78 & & 1.67 & \\
\hline
\end{tabular}

* Mean temperatures for December, January, February; cases for January, February, March

$\uparrow$ Temperatures for June, July and August; cases for July, August and September.

small, and usually statistically insignificant, amount to the coefficients of determination (Table 1). For none of the divisions was the contribution of winter temperature statistically significant. Readshaw's finding of a significant effect of winter temperature is an artefact of pooling heterogeneous data, as is suggested by Table 2 . Texas is climatologically and ecologically heterogeneous and is therefore not a useful biogeographical unit ${ }^{2}$.

It has long been advocated by programme spokesmen that exceptional weather can have dramatic effects on screwworm incidence. The eradication programme in Florida was rushed forward to take advantage of the very cold winter of 1957-58 The disastrous setback to the programme in the southwestern United States in 1972 is attributed by Graham and Hourrigan ${ }^{4}$ and by Bushland $d^{5}$ at least partly to the exceptional weather.

However, this is all ancient history now that eradication has been announced ${ }^{6}$ in Mexico south to the Isthmus of Tehuantepac, thus cutting off the source of immigrant flies which used to frustrate the efforts of the southwestern US programme. There have been no cases in the United States since $1982^{5}$ and Pineda-Vargas? has tabulated cases in Mexico from the first full year (1977) of sterile male production in Chiapas, Mexico, up to 1984 and these data are updated in Table 3. Does Readshaw claim that this steady suppression of the pest and its confinement to 